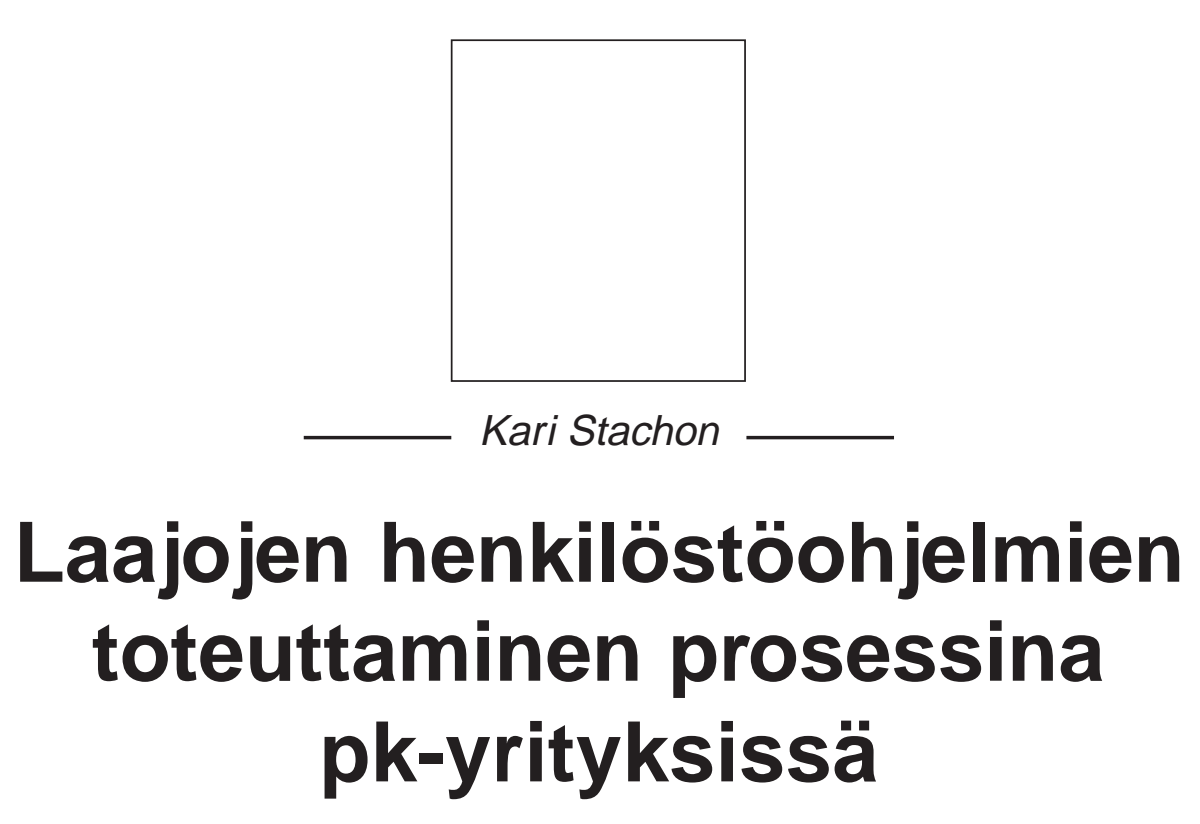

\begin{abstract}
Pirkan oppivat organisaatiot -projekti käynnistettiin Euroopan rakennemuutosrahaston rahoittamana hankkeena vuoden 1997 alusta, ja projekti päättyy vuoden 1999 lopussa. Hankkeen vastuullinen toteuttaja on Työväen Sivistysliitto opintokeskus ry., ja projektin käytännön toteuttamisesta on vuoden 1997 keväästä vastannut kaksi päätoimista työntekijää Tampereella.
\end{abstract}

O ppivat organisaatiot -projektin tavoitteena on, kuten yleensäkin ESR-hankkeissa, luoda uusia käytäntöjä ja innovaatioita pk-sektorin kehittämiseksi. Projekti on kolmivuotinen, ja tarkoituksena on, että kohteena olevissa yrityksissä käynnistetään prosesseja, jotka jatkuvat yrityksissä projektin loppumisen jälkeenkin. Tällä hetkellä projektissa on mukana noin 15 yritystä, joissa toimet kohdistuvat suoraan noin 900 henkilöön.

Projektin käytännön tehtävänä on luoda pk-sektorille sellaisia henkilöstöhankkeita, joiden toteuttamiseen osallistuu koko yrityksen henkilöstö. O ppivat organisaatiot - projektin kohteita ei ole rajattu esim. vain tiettyjen toimialojen yrityksiksi, mutta projektin ollessa noin vuoden ikäinen, yli puolet mukana olevista yrityksistä on metalliteollisuutta. Seuraavassa kuvataan Iyhyesti henkilöstöhankkeen etenemistä kahdessa erityyppisessä yrityksessä, joista toinen on 70 henkilön metalliteollisuusyritys, ja toinen 23 henkilön myynti/ markkinointiorganisaatio.

\section{Metalliyritys, 70 henkeä}

Ensimmäinen yhteydenotto yritykseen tehtiin alkuvuodesta 1997. Sovittuamme toimitusjohtajan kanssa tapaamisesta, lähdimme käymään yrityksessä kertoaksemme, mitä konkreettista O ppivat organisaatiot - projekti voisi tarjota yritykselle. Ensimmäisessä palaverissä paikalla oli yrityksen toimitusjohtaja ja O ppivat organisaatiot - projektin edustaja. Tuloksena tapaamisesta projekti toimitti paperille kirjattujen ranskalaisten viivojen listasta hieman jalostetun ehdotuksen siitä, millainen kehitysohjelman runko voisi sisällöltään ja aihealueiltaan olla. Tämän kehitysohjelmaehdotuksen sisällöistä keskusteltiin vielä kahdessa tapaamisessa.

K esälomien jälkeen päätettiin asian eteenpäin viemiseksi pitää koko päivän kestävä johdon 
työseminaari tavoitteiden asettamiseksi. Työseminaariin tuli mukaan edustus myös alueen kolmesta muusta yrityksestä, joissa kiinnostuttiin O ppivat organisaatiot -hankkeesta isoimman yrityksen kiinnostuttua siitä. Kaikki kolme muuta työseminaariin osallistunutta yritystä olivat saman alueen metalliyrityksiä, kooltaan 35, 10 ja 10 henkeä. Ensimmäisessä vaiheessa yrityksen johdon tai omistajan vakuuttaminen henkilöstön kehittämisen kannattavuudesta on ensiarvoisen tärkeää, sillä tuotantotyöntekijöiden irrottaminen koulutuksiin on yritykselle huomattavan kallista palkkakustannuksina. Lisäkustannuksia tulee myös tuotannon hidastumisesta.

Seuraavassa vaiheessa järjestettiin konsultin vetämä päivä kaikille yrityksen työntekijöille, yhteensä yli sadalle hengelle. Päivän tarkoitus oli koostaa henkilöstöstä nousevia kehittämistarpeita. K uten odotettua, henkilöstöltä kysyttäessä tarpeet olivat hieman erilaisia kuin millaisiksi yritysten johto oli ne arvioinut. Esimerkiksi johdon käsitys siitä, että tiimityöskentelyä pitäisi kehittää yrityksissä, ei juurikaan herättänyt henkilöstössä vastakaikua. Suurimmat tarvealueet henkilöstöltä kysyttäessä olivat: parempi työn suunnittelu, ammattitaidon lisääminen, työympäristön viihtyvyys, sekä johdon ja työntekijöiden keskusteluyhteyden parantaminen.

O hjelmaa konkretisoitiin tästä eteenpäin pitämällä yhteispalaveri, jossa oli mukana yritysten johdon lisäksi tuotannon työntekijöitä, mm. luottamusmiehet. Luottamusmiehiä oli jo aiemminkin informoitu siitä, että yrityksessä suunnitellaan henkilöstön kehittämisohjelmaa, ja nyt oli tarkoitus rakentaa lihaa luiden ympärille siitä lähtökohdasta, että tuotannon edustajat pääsevät suoraan vaikuttamaan koulutuksen sisältöön. Tärkeää on, että hankkeelle muodostuu yhteinen kieli ja ajattelu kehittämistoiminnan tärkeydestä. N ämä asiat ovat asennetasolla puolin ja toisin, ja kehittämistoimien tulee olla tarpeeksi konkreettisia.

Seuraavassa vaiheessa järjestettiin yritystalouden perusasioita käsittelevä koulutuspäivä kaik- kien neljän yrityksen koko henkilöstölle. $\mathrm{K}$ ahdessa suurimmassa yrityksessä päivän sisältö suunniteltiin yksilöllisesti yrityksen lähtökohdista, ja kahden pienemmän yrityksen osalta päivän sisältö oli samanlainen. Päivän vetämisen käytännön toteutuksesta vastasi eri konsultti kuin aiemmista tilaisuuksista syystä, että konsultilta vaadittiin metalliteollisuuden käytännön tuntemusta, eli jonkinlaista työuraa metalliyrityksissä. Sopivan taustan omaavan konsultin löytäminen ei ollut aivan yksinkertaista. Projektissa kouluttajina toimivat konsultit valitaan siten, että heidän aiempiin referenssiyrityksiinsä otetaan yhteyttä ja yrityksiltä tiedustellaan heidän konsultointikäytännöistään.

K evään 1998 aikana toteutetaan puheena olevissa metalliyrityksissä koulutusta tiimityöskentelyyn ja esimiesvalmennukseen, uskallukseen esittää omia mielipiteitä, yhteistyövalmiuksien kehittämiseen ja työympäristö- ja työturvallisuuskysymyksiin.

Projektin kohteena olevissa yrityksissä on käynnistynyt prosesseja, joiden lopullinen päämäärä on muuttaa yritysten kulttuuria yhteistyöhakuisemmaksi ja avoimemmaksi. Joitakin asioita voidaan jo sanoa yrityksissä tapahtuneen, ja aika näyttää jatkon onnistumisen. Y rityksen ilmapiiriin liittyvät asiat ovat pitkäjänteisiä ja muutokset suuntaan jos toiseen hitaita. Y ritys sijaitsee vanhalla tehdaspaikkakunnalla, jossa kaupunki on aikanaan kasvanut ns. piipun juurelle. Perinteiset vastakkainasettelut työnantaja- ja tekijäpuolella ovat siellä vielä voimissaan, mutta työilmapiiri on parantunut henkilöstön osallistumismahdollisuuksien lisääntymisen jälkeen. K aikessa vuonna 1998 toteutettavassa koulutuksessa sisältöjen suunnittelussa on mukana henkilöstön edustus, yleensä luottamusmies ja toinen tuotantotyöntekijä.

\section{Myynti/markkinointiyritys, 23 henkeä}

K eväällä 1997 projekti aloitti yhteistyön 23 hengen myynti/ markkinointiyrityksen henkilöstön kehittämiseksi, tavoitteena oli aluksi lähin- 
nä organisaation työtapojen tiimiytys. Y rityksen henkilöstö rakentuu siten, että 6 inmistä hoitaa yleishallintoa ja tuotekehitystä, ja 17 myynti-insinööriä on asiakastyössä ympäri Suomen. O rganisaation alueellinen hajanaisuus aiheuttaa omat ongelmansa, ja yrityksen liikevaihto juuttui pari vuotta sitten 10 miljoonan markkan tasolle. Y ritysten tavoitteena oli tehostaa toimintaa ja nostaa liikevaihto kasvuun. $\mathrm{N}$ äiden tavoitteiden saavuttamiseksi ei laiteinvestoinneista ole hyötyä johtuen siitä, että yritys ei ole kappaletavaraa tuottava.

Pirkan oppivat organisaatiot -projekti järjesti aivan vuoden 1997 alussa, heti käynnistymisensä jälkeen, tiedotustilaisuuden, josta ilmoitettiin paikallisessa valtalehdessä. T iedotustilaisuudessa esiteltiin projektia lyhyesti, ja ohjelmaan oli myös otettu ulkopuolinen luennoitsija kertomaan yleisesti tiimityöstä, koska aiheen arveltiin kiinnostavan yrityksiä. Paikalle vaivautui vain kymmenkunnan yrityksen edustajia, joista yksi oli tässä tapausselostuksessa kerrotun yrityksen toimitusjohtaja. Tilaisuuden jälkeen yrityksen johtaja halusi kuulla lisää projektista, ja sovimme tapaamisesta.

K eväällä 1997 projektin edustajat ja yrityksen 2 johtajaa (samalla myös omistajat) tapasivat useita kertoja, kun tavoitteita yrityksen kehittämiseksi yritettiin määrittää. Palavereja kertyi suhteellisen paljon siksi, että yrityksen tavoitteet eivät olleet selviä itse yrityksellekään. Alkusuunnittelulle tyypillisiä ranskalaisten viivojen listoja syntyi monia, ja vaikeutena oli rajata asioita siten, että saataisiin aikaiseksi jäntevä ja vain tiettyihin pääkohtiin keskittyvä kehittämissuunnitelma.

Lopulta päädyttiin kahteen pääkohtaan: tiimityöskentelyn luomiseen ja tietojärjestelmän kehittämiseen. Pirkan oppivat organisaatiot -projektin painopisteeksi sovittiin tiimityöskentelyvalmiuksien luominen ja itse toimivien tiimien luominen, sillä tietojärjetelmän kehittäminen on osa yrityksen perinteisen liiketoiminnan kehittämistä, kun taas 0 ppivat organisaatiot -projektin yhdeksi tavoitteeksi on kirjattu uusien inhimillisten käytäntöjen luominen.
K oulutus aloitettiin toukokuun alussa 1997 järjestämällä yrityksen koko henkilöstölle koulutuspäivä tiimiasioista: mitä hyötyä niistä on, miten ne voisivat palvella yrityksen tarpeita käytännössä ja muita yleisiä asioita tiimeistä. Päivän vetäjäksi projekti etsi tiimikouluttajan. Seuraava tilaisuus tiimiasioista järjestettiin heti kesäkuussa, ja sen jälkeen yrityksestä ilmaistiin halukkuus vaihtaa konsulttia. Syy tähän oli, että työt yrityksen kanssa aloittanut henkilö oli kouluttaja, siis enemmän luennoitsija kuin osallistuva konsultti. Projekti etsi jatkoa varten sopivamman konsultin, joka onkin jatkanut työtään yrityksen kanssa siitä lähtien.

Vuonna 1997 yrityksellä oli yksitoista Pirkan oppivat organisaatiot -projektin organisoimaa koulutuspäivää. M äärä on suuri, mutta toimitusjohtajan kommentin mukaan investointi on ollut erittäin kannattava, sillä yrityksen liikevaihto kasvoi tiimien toiminnan aloittamisen jälkeen peräti kaksikymmentä prosenttia. $0 \mathrm{n}$ tietenkin mahdotonta sanoa, mikä osuus toimintojen tiimiyttämisellä on ollut liikevaihdon kasvuun suoranaisesti. Y rityksen mukaan heidän ulkoisessa liiketoimintaympäristössään ei kuitenkaan ole tapahtunut mitään sellaista, joka selittäisi noin suuren liikevaihdon kasvun.

K äytännössä vuoden 1997 lopussa yrityksessä 17 myynti-insinöörin joukko on jaettu alueellisesti viideksi tiimiksi, joista kaksi toimii erittäin hyvin, kaksi keskinkertaisesti ja yksi huonosti. O n syytä tähdentää, että toimivan tiimin luominen voi olla vaikeaa henkilö- ja muistakin asioista riippuen, ja näihin vaikeuksiin on syytä varautua tiimejä perustettaessa.

Tiimiyttämisen yhteydessä luotiin myös sitä tukeva palkkiojärjestelmä. Myynti-insinöörit saavat entiseen tapaan peruspalkan ja henkilökohtaisen provision, mutta uutena asiana parhaan tuloksen tehnyt tiimi palkitaan sekä rahallisesti että maksamalla viikon etelänmatka. K onkreettinen kannustejärjestelmä auttaa suuresti uusien toimintatapojen läpiviemistä yrityksissä, sillä työntekijöiden täytyy nähdä myös henkilökohtainen hyötynsä uusiin toimintatapoihin siirryttäessä. Tärkeänä asiana tuli vuo- 


\section{KAISAUSA}

den 1998 alussa myös ilmi, että henkilöstön keskinäinen kilpailu on vähentynyt ja työtyytyväisyys parantunut.

Y rityskulttuuriin toimintatapojen muutokset ovat vaikuttaneet selvästi henkilöstön mielipiteiden ja näkemysten lisääntyneenä huomioimisena yrityksen asioita koskevassa päätöksenteossa. K oko yrityksen henkilöstö kootaan säännöllisesti yhteen, ja ongelmat sekä mahdolliset epäkohdat keskustellaan ja niihin puututaan "maton alle" lakaisemisen sijasta. O n erittäin tärkeää, että kun vanhoja toimintatapoja muutetaan, niin muutosten vaikutuksista kerätään henkilöstöltä jatkuvasti palautetta. Motivaatio omaan työhön varmasti kasvaa, kun henkilöstö tietää, että heidän palautteensa pohjalta myös toteutetaan muutoksia.

K uvatussa yrityksessä yhteistyö yrityksen ja Pirkan oppivat organisaatiot -projektin välillä jatkuu, ja tarkoituksena on jättää yrityksen jatkuvasta kehittämisestä yhä enemmän suunnittelu- ja toteutusvastuuta yritykselle itselleen, jolIoin se on riippumaton määräaikaisesta projektista.

\section{Onnistumiselle tärkeät asiat}

- Jos pyritään todellisiin tuloksiin ja pitkäjänteiseen henkilöstöpolitiikkaan, niin kehittämistoimet on kohdistettava suoraan koko henkilöstöön, jolloin ihmiset tuntevat olevansa mukana asiassa.

- Koko henkilöstön mielipiteitä kannattaa kysyä jo suunnitteluvaiheessa.

- Aivan alussa yrityksen ylimmän johdon vakuuttaminen on välttämätöntä, sen jälkeen tuotantohenkilöstön edustus tulee saada mukaan mahdollisimman nopeasti.

- H yödyt yritykselle on pystyttävä osoittamaan jollain aikavälillä, vuosi lienee sopiva aikajänne.

- Muutosprosessi täytyy pitää käynnissä yrityksessä, eli alkuinnostuksen jälkeen seuraavista tilaisuuksista ja aiheista pitää sopia mahdollisimman nopeasti.

- Y rityksestä pitäisi löytää henkilö, joka vas- taa kehitysohjelmasta yrityksessä ja toimii yhdyshenkilönä projektiin päin; muutoin suunnitelmien toteuttamisesta ei helposti vastaa kukaan, ja asiat jäävät puolitiehen.

- K ehittämisen on lähdettävä yrityksen tarpeista! K ahta samanlaista yritystä ei ole.

- Jokaisen tilaisuuden jälkeen niiden onnistuminen on tarkastettava.

\section{Sudenkuopat}

- Tarjotaan yritykselle valmis koulutusohjelma, joka ei pohjaa yrityksen tarpeisiin. O ppi-

\section{Käsityksiä oppivasta organisaatiosta}

O ppiva organisaatio ei ole käsitteenä yksiselitteinen. Voidaan helposti erottaa ainakin kolme näkökulmaa oppivaan organisaatio on:

1. K yberneettis-systeemiseen ajatteluun pohjautuvista malleista ensimmäisiä mainintoja lienee Cyert-M archin kirjoituksissa 1963, ja nykyään tunnetuin ajatusten esiintuoja on amerikkalainen Peter Senge. Tunnusomaista malleille on vahva pitäytyminen systeemiajattelussa. o rganisaatio mielletään vuorovaikutusjärjestelmäksi, jonka toiminnot vaikuttavat kaikki toisiinsa ja jonka mekanismeja voi tietoisesti muuttaa.

2. Oppijalähtöiset mallit: esimerkiksi D avid Kolbin tai Burgoyne \& Pedler \& Boydell -kolmikon käsitykset siitä, miten yksilön oppiminen ohjataan organisaation pääomaksi ja vahvuustekijäksi.

3. Laatuajattelulähtöiset mallit näkökulmana oppivaan organisaatioon; ajatusten suomalaisina edustajina ovat esimerkiksi Urpo ja Anita Sarala kirjoituksineen. Laatulähtöisissä malleissa henkilöstön kehittäminen nähdään osana yrityksen yleistä laatuajattelua ja sen systemaattista kehittämistä. 
laitokset tarjoavat ohjelmia, projektit kysyvät, kohdeyrityksille, laatuajatteluun jollain tavalla mitä tarvitaan, ja tekevät ohjelman sen mukaan! liittyvät asiat menivät paremmin "perille" yri- Mennään mestaroimaan yritykseen asenteella, tysten johtajille kuin jotkin inmisläheiset tai ykettä "nyt kerron, miten teillä pannaan asiat kun- silön tarpeista lähtevät mallit.

toon". Liittyy osin edelliseen kohtaan.

- Ei pidetä yhteyttä yritykseen riittävästi. H enki- Käytännössä projektin työ tehdään kuitenkin lökohtaiset käynnit, lyhyetkin, ovat tärkeitä pro- tuotantohenkilöstön kanssa, sillä kuluneen puojektin ollessa käynnissä. Paljon voi hoitaa puhe- lentoista vuoden aikana esimerkiksi metallitelimitsekin, mutta ei rakentaa tarvittavaa henki- ollisuudesta saatu viesti on sellainen, että noin lökohtaista luottamusta. 30 prosenttia tuottavuuden paranemisesta voi- Y rityksessä on käynnissä liikaa erilaisia kehit- daan saavuttaa uusilla laiteinvestoinneilla ja tämisprojekteja liian lyhyellä aikavälillä. johdon kouluttamisella ja 70 prosenttia tuottavuuden lisäyksestä on saatavissa vain tuotanto-

Pirkan oppivat organisaatiot -projektin näkökul- työntekijöiden suoralla koulutuksella esimerkikma oppivaan organisaatio on on lähimpänä kol- si tiimi- tai laatuajatteluun. matta näkökulmaa eli laatuajattelulähtöisiä mal-

leja (ks. luokittelu laatikossa edellisellä sivulla). Sopivien konsulttien löytäminen on hankalaa, Tämä johtuu siitä, että projektissa mukana ole- kun konsultin pitää toimia suoraan tuotantovat yritykset ovat suurimmaksi osaksi perusteol- työntekijöiden kanssa. U seimmilla O ppivat orlisuutta, eli kappaletavaratuotannollisia. Perintei- ganisaatiot - projektin konsulteilla on metallisessä teollisuudessa työ on usein vuoro-työtä ja teollisuuden tausta ja teknillinen koulutus. työtehtävät on ositettu. K un O ppivat organisaatiot - projektia markkinoitiin nykyisille projektin 